\title{
The dawn of metal-oxo clusters as artificial proteases: from discovery to the present and beyond
}

\author{
Francisco de Azambuja ${ }^{1}$, Jens Moons ${ }^{1}$ and Tatjana N. Parac-Vogt ${ }^{1 *}$ \\ ${ }^{1}$ Department of Chemistry, KU Leuven, Celestijnenlaan 200F, 3001 Leuven, Belgium
}

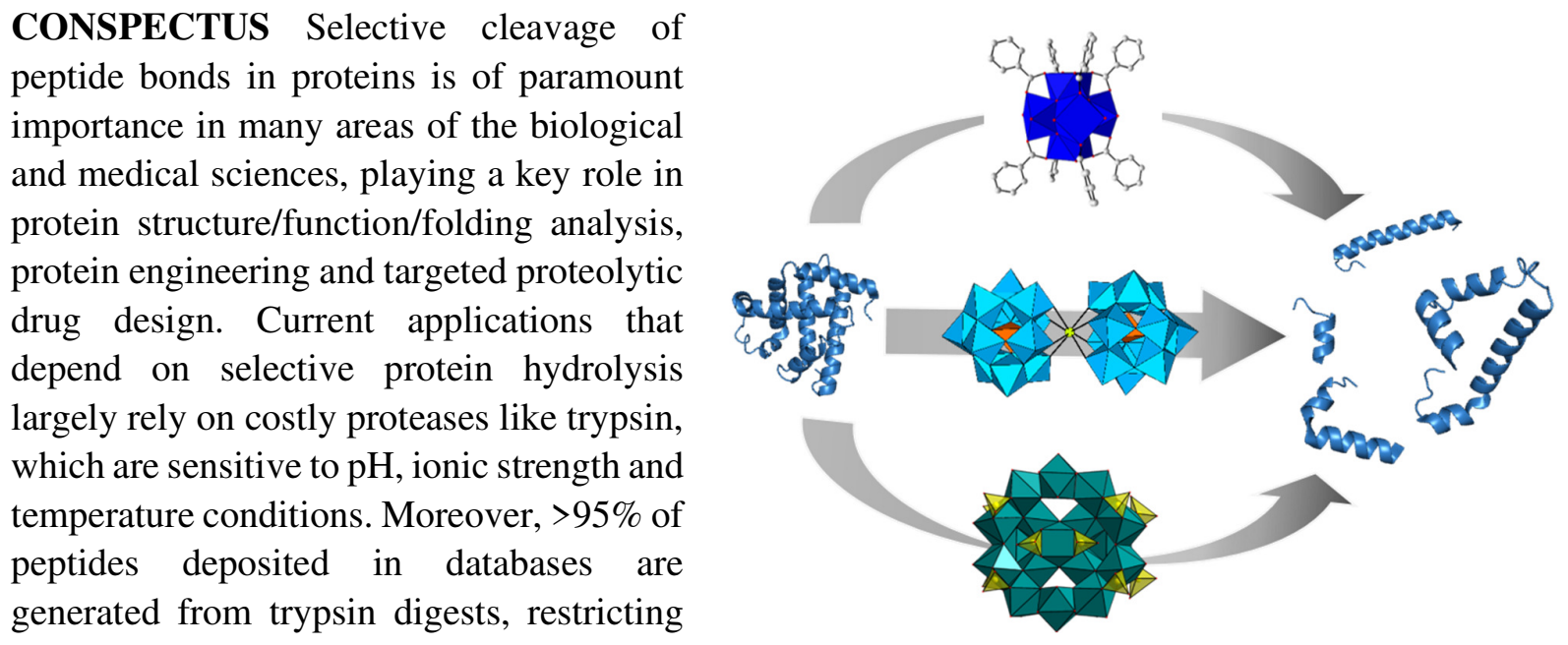
the information within the analyzed proteomes. On the other hand, harsh and toxic chemical reagents like $\mathrm{BrCN}$ are very active but cause permanent modifications of certain amino acid residues. Consequently, transition metal complexes have emerged as smooth and selective artificial proteases owing to their ability to provide larger fragments and complementary structural information. In the last decade, our group has discovered the unique protease activity of diverse metal-oxo clusters (MOC), and pioneered a distinctive approach for the development of selective artificial proteases. In contrast to classical coordination complexes which often depend on amino acid side chains to control regioselectivity, the selectivity profile of MOCs is determined by a complex combination of structural factors, such as protein surface charge, metal coordination to specific side chains, and hydrogen bonding between the protein surface and the MOC scaffold.

In this account, we present a critical overview of our detailed kinetic, spectroscopic and crystallographic studies in MOC-assisted peptide bond hydrolysis, from its origins to the current rational and detailed mechanistic understanding. To this end, reactivity trends related to structure and properties of MOCs based on the hydrolysis of small model peptides, and key structural aspects governing the selectivity of protein hydrolysis are presented. Finally, our endeavors in seeking the next generation of heterogeneous MOC-based proteases are briefly discussed by embedding MOCs in metal-organic frameworks or using them as discrete nanoclusters in the development of artificial protease-like materials, i.e. nanozymes. The deep and comprehensive understanding sought experimentally and theoretically over the years in aqueous systems with intrinsic polar and charged substrates provides a unique view of the reactivity between inorganic moieties and biomolecules, thereby broadly impacting several different fields e.g., catalysis in biochemistry, inorganic chemistry and organic chemistry. 


\section{KEY REFERENCES}

1. Mihaylov, T. T.; Ly, H. G. T.; Pierloot, K.; Parac-Vogt, T. N., "Molecular Insight from DFT Computations and Kinetic Measurements into the Steric Factors Influencing Peptide Bond Hydrolysis Catalyzed by a Dimeric Zr(IV)-Substituted Keggin Type Polyoxometalate." Inorg. Chem. 2016, 55, 9316-9328. https://doi.org/10.1021/acs.inorgchem.6b01461

One of our theoretical studies that helped to consolidate the proposed mechanism for the metalsubstituted POM catalyzed peptide bond hydrolysis by examining the speciation, coordination chemistry and effect of amino acid's side-chains on the reaction energetics. ${ }^{1}$

2. H. G. T. Ly, T. T. Mihaylov, P. Proost, K. Pierloot, J. N. Harvey, T. N. Parac-Vogt, "Chemical Mimics of Aspartate-Directed Proteases: Predictive and Strictly Specific Hydrolysis of a Globular Protein at Asp-X Sequence Promoted by Polyoxometalate Complexes Rationalized by a Combined Experimental and Theoretical Approach" Chem. Eur. J. 2019, 25, 14370-14381. https://doi.org/10.1002/chem.201902675

Rationalization of the molecular origins of the predominant cleavage of proteins at Asp-X residues observed for metal-substituted POMs by combining experimental and theoretical approaches, which relied on reactivity and interaction data to examine different hydrolysis mechanisms of Asp-X bond in protein environments. $^{2}$

3. Vandebroek, L.; De Zitter, E.; Ly, H. G. T.; Conić, D.; Mihaylov, T.; Sap, A.; Proost, P.; Pierloot, K.; Van Meervelt, L.; Parac-Vogt, T. N., "Protein-Assisted Formation and Stabilization of Catalytically Active Polyoxometalate Species." Chem. Eur. J. 2018, 24, 10099-10108. https://doi.org/10.1002/chem.201802052

Experiments and theory enabled a unique view of the influence of a protein in the structure, solution behavior and reactivity of metal-substituted POMs. Lower relative permittivity nearby protein surfaces stabilization of the 1:1 metal-POM catalytic active complex allowed the first experimental observation of this elusive species. ${ }^{3}$

4. Ly, H. G. T.; Fu, G.; Kondinski, A.; Bueken, B.; De Vos, D.; Parac-Vogt, T. N., "Superactivity of MOF-808 toward Peptide Bond Hydrolysis." J. Am. Chem. Soc. 2018, 140, 6325-6335. https://doi.org/10.1021/jacs.8b01902

Our seminal work developing heterogeneous proteolytic nanozymes uncovered the potential of MOFs as efficient, practical and selective artificial metalloproteases. ${ }^{4}$ 


\section{INTRODUCTION}

One of the main challenges in the development of new catalysts for protein hydrolysis is site selectivity. In nature, evolution resulted in very efficient and selective proteases, a class of enzymes which nowadays also play a key role in modern science owing to the emergence of proteomics ${ }^{5,6}$ and targeted protein degradation drug development. ${ }^{7,8}$ These fields are the basis of several other biomedical areas and largely depend on protein structure and function determination, which in turn requires controlled and selective protein cleavage to streamline analysis. Despite being widely applied in these contexts, natural enzymes are expensive and highly sensitive to reaction conditions. Moreover, they often give rise to short fragments, which limits the information retrieved from parent protein structures. Therefore, new chemical approaches for selective protein cleavage are highly desirable, and the development of selective artificial proteases has gained prominence. ${ }^{9,10}$

Metal-oxo clusters (MOCs) are a vast class of compounds, with a rich history in inorganic chemistry. ${ }^{11,12}$ These clusters have been frequently regarded as discrete soluble intermediates of polymeric metal oxides, and possess extremely attractive physicochemical properties for the development of catalysts, electronic and photochemical devices with a plethora of potential applications in chemistry and technological areas. ${ }^{13-15}$ In addition, MOCs exhibit promising antiviral, -bacterial and -cancer activity, ${ }^{16-19}$ and have been long-established in crystallographic studies with protein and nucleic acids. ${ }^{20}$ Such prominent chemistry between MOCs and biomolecules inspired us to study their virtually unexplored reactivity with biomolecules. Our initial studies focused on the reactivity of MOCs towards DNA and RNA model systems. Surprisingly, these anionic phospho-esters were hydrolyzed in the presence of $\left[\mathrm{Mo}_{7} \mathrm{O}_{24}\right]^{6-}$ and $\left[\mathrm{V}_{4} \mathrm{O}_{12}\right]^{4-}$ despite the high negative charge of these metal clusters, ${ }^{21,22}$ indicating that this reactivity could be more than a mere curiosity and prompting further exploration with other biomolecules such as proteins.

In this account, we review the hydrolytic reactivity of MOCs toward peptides and proteins developed over the past decade. Among the several types of MOCs, most of our efforts were directed to the reactivity of anionic polyoxometalates (POMs) due to their aqueous solubility and well-developed chemistry. This initial interest recently evolved to insoluble MOCs and metal-organic frameworks (MOFs), which provide interesting complementary properties, such as the ease of catalyst separation due to the heterogeneous nature of reaction. Overall, relying on a multidisciplinary and multi-technique approach, our findings uncovered key aspects correlating interaction and reactivity between MOCs and proteins, which may be useful for bio-, medicinal, and catalysis chemists across different areas of science. $^{23}$ 


\section{FUNDAMENTALS IN THE REACTIVITY OF POMs AND PEPTIDES}

Before engaging in the hydrolysis of proteins, the hydrolytic activity of POMs was developed using small, commercially available dipeptides as model substrates. Inspired by the phosphoesterase activity observed in our early work, isopolyoxomolybdates ${ }^{24}$ and -vanadates ${ }^{25}$ were investigated under physiological pH conditions. In general, higher hydrolytic activity was consistently observed for Sercontaining dipeptides, most likely due to the presence of the $\mathrm{OH}$ group in the Ser side chain which is able to engage in a well-established N,O-acyl rearrangement mechanism. ${ }^{24,25}$ Although this reactivity proved useful later in protein hydrolysis, ${ }^{26}$ molybdates and vanadates have an inherent dynamic behavior in solution that is difficult to control and study, thereby hampering optimization of their activity due to the uncertainty regarding the catalytically active species. ${ }^{27}$ Therefore, this intrinsic challenge in controlling the speciation motivated the search for more stable catalysts based on POM clusters.

Among the available MOCs, phosphotungstate based POMs were the most suitable for further development as catalysts (Figure 1). Phosphotungstate clusters are stable over broad $\mathrm{pH}$ and temperature ranges. Moreover, their lacunary derivatives can bind various Lewis acidic metal ions, which results in metal-substituted POMs (M-POMs) with additional catalytic properties. The speciation and solution behavior of these M-POMs can be easily followed by ${ }^{31} \mathrm{P}$ NMR spectroscopy, rendering them highly convenient and designable catalysts. Accordingly, the ready availability of several metal-substituted phosphotungstates allowed us to quickly obtain an overview of their hydrolytic activity toward the peptide bond using glycylglycine (Gly-Gly) dipeptide as a model substrate. ${ }^{28}$ 


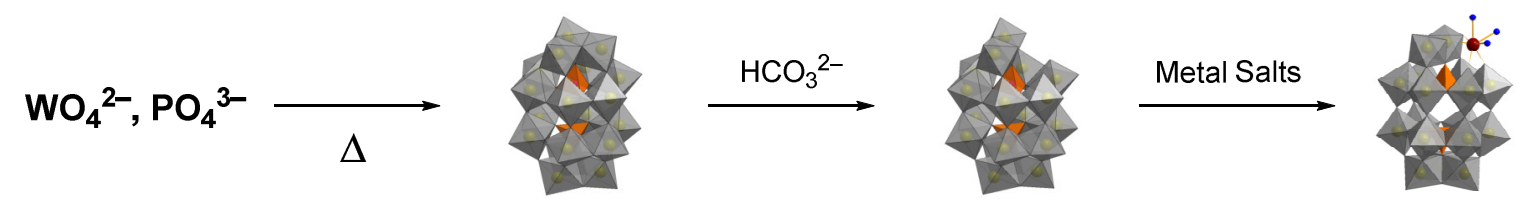

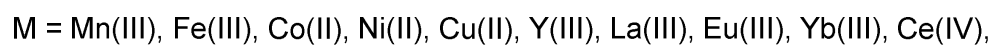

$\mathrm{Zr}(\mathrm{IV})$, and $\mathrm{Hf}(\mathrm{IV})$

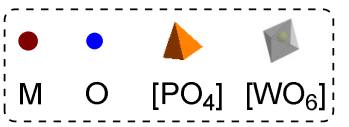

b) General structure of $\mathrm{M}-\mathrm{POMs}\left(\mathrm{M}=\mathrm{Zr}^{\mathrm{IV}}, \mathrm{Hf}^{\mathrm{IV}}, \mathrm{Ce}^{\mathrm{IV}}\right)$ that exhibited hydrolytic activity towards peptide bonds

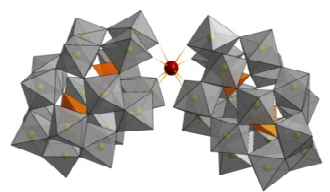

[M( $\left.\left.\alpha_{2}-\mathrm{P}_{2} \mathrm{~W}_{17}\right)_{2}\right]$

$\alpha_{2}$-Wells-Dawson 1:2

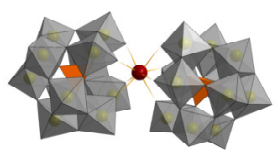

$\left[\mathrm{M}\left(\mathrm{PW}_{11}\right)_{2}\right]$

Keggin 1:2

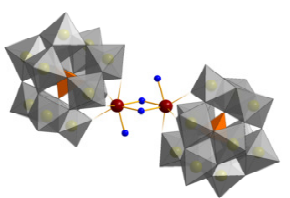

$\left[\mathrm{M}\left(\mathrm{PW} \mathrm{W}_{11}\right)\right]_{2}$

Keggin 2:2

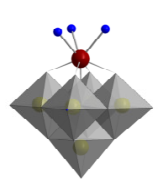

$\left[\mathrm{M}\left(\mathrm{W}_{5}\right)\right]$

Lindqvist 1:1

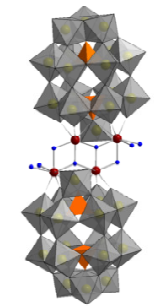

$\left[\mathrm{M}_{4}\left(\mathrm{P}_{2} \mathrm{~W}_{16}\right)_{2}\right]$

Wells-Dawson 4:2

Figure 1: Metal-substituted polyoxometalates (M-POMs) are highly designable/tunable catalysts readily available from inexpensive inorganic salts. Color code: metal (dark-red spheres), oxygen (blue spheres), [ $\left.\mathrm{PO}_{4}\right]$ (orange tetrahedra), $\left[\mathrm{WO}_{4}\right]$ (grey octahedra)

The nature of the embedded Lewis acid, the POM structure and the metal/POM ratio in the catalyst each influenced the hydrolysis rate of Gly-Gly by metal-substituted POMs. Early on, we observed the superior reactivity of $\mathrm{Zr}(\mathrm{IV}), \mathrm{Hf}(\mathrm{IV})^{28}$ and $\mathrm{Ce}(\mathrm{IV})^{29}$ analogues over first-row transition metals and trivalent lanthanide substituted POMs, presumably due to the stronger Lewis acidity of the +4 stable oxidation states, and the higher coordination numbers that these metals can adopt. On the other hand, hydrolysis was observed regardless of the nature of POM ligand, albeit different reaction rates were obtained depending on the type of M-POM complex used (Scheme 1). In general, the higher activity should be expected for catalysts in which the embedded Lewis acid metal ion has free coordination sites to interact with the substrate. Accordingly, faster Gly-Gly hydrolysis was observed for Zr-Wells Dawson 1:2 and Zr-Keggin 2:2, which are prone to generate a 1:1 species in solution (Scheme 2). Such mechanism is also consistent with the low activity of the coordinatively saturated Zr-Keggin 1:2, which only dissociates partially under the reaction conditions, ${ }^{30}$ and with the good reactivity observed for the Zr-Wells-Dawson 4:2 complex, which despite not undergoing dissociation, intrinsically contains coordinatively unsaturated $\mathrm{Zr}(\mathrm{IV})$ sites in its structure (Figure 1). ${ }^{31}$ 


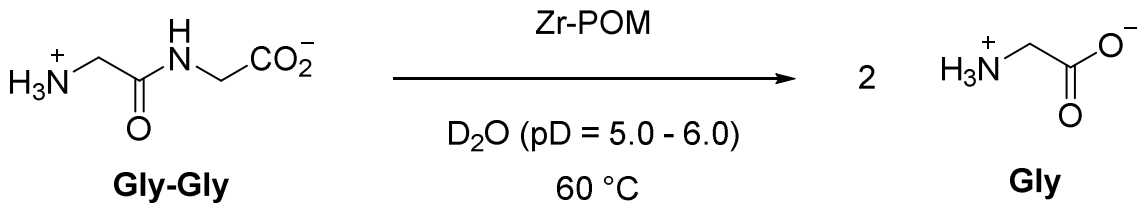

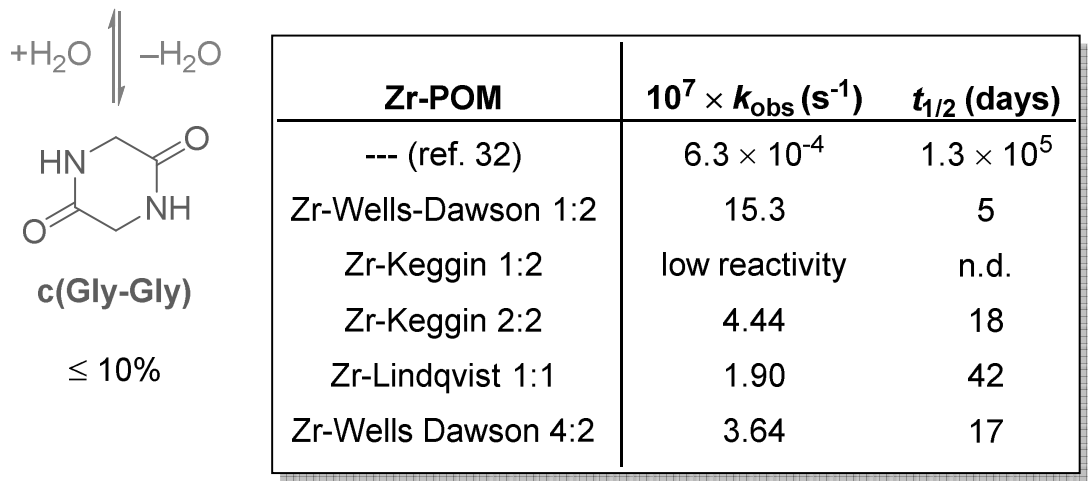

Scheme 1: Structure of the Zr-POM catalyst influences the rate of peptide bond hydrolysis compared to the uncatalyzed, spontaneous hydrolysis of glycylglycine under the same reaction conditions ${ }^{32}$

Mechanistic experiments and Density Functional Theory (DFT) calculations further confirmed that metal-substituted POMs accelerate peptide bond hydrolysis through a Lewis acid activation mechanism, which requires free coordination sites at the embedded metal center (Scheme 2). Thus, initial dissociation of M-POMs precursors determines the availability of the metal-POM 1:1 catalytically active species (A), which in turn accounts for the influence of M-POM structure on reaction rate. Similar trend has been also observed in several organic solvents. ${ }^{33} \mathrm{Next}$, coordination of the dipeptide substrate can happen in several ways $(\mathbf{B})$, but dipeptide chelation through the $\mathrm{N}$-terminal amino group and an amide carbonyl oxygen is the major reactive intermediate $(\mathbf{C})$. In this species, synergistic Lewis acid activation of the amide carbonyl group and the $\mathrm{C}$-terminal carboxylate assisted water deprotonation decreases the energy barrier of an outer-sphere water nucleophilic attack, leading to peptide bond cleavage. ${ }^{1,31}$ In addition to hydrolysis, the correspondent cyclic dipeptide is also transiently formed in these reactions, probably derived from a 'non-productive' coordination mode in B. The M-POMs mediated 'fast equilibrium' between Gly-Gly and 2,5-diketopiperazine, ${ }^{32}$ was also recently exploited, disclosing M-POMs as a new class of atom-economic and water tolerant amide bond forming catalysts. ${ }^{34}$ 


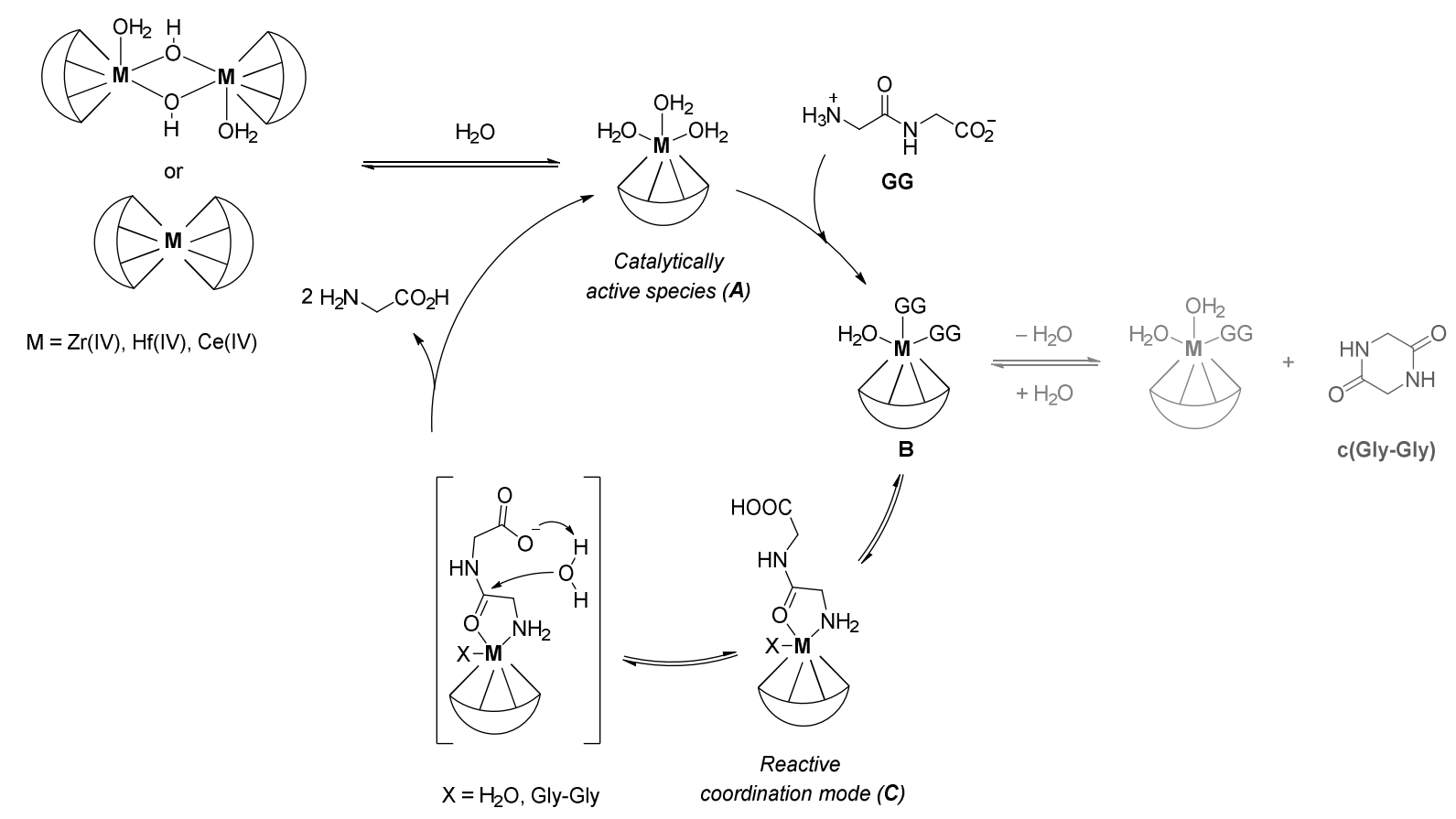

Scheme 2: General mechanism proposed for the peptide bond hydrolysis catalyzed by metal-substituted POMs

Once the basic catalytic activity towards the peptide bond hydrolysis was developed, we also evaluated a large variety of dipeptides to probe the role of side-chains in reactivity. A range of different Gly-Aa $(\mathrm{Aa}=$ amino acid $)$ dipeptides was successfully hydrolyzed; however, the reaction rates were largely dependent on the nature of the side-chain group in Aa. The reaction rates were particularly sensitive to steric hindrance, and bulky side chains slowed the hydrolysis rate (Figure 2). ${ }^{31}$ Such behavior is consistent with a less effective substrate-catalyst interaction, proposed in Scheme 2, since the substrate undergoes conformational changes to encounter the entering water molecule, and this can be hampered by bulky substituents. ${ }^{1}$ On the other hand, serine containing dipeptides consistently showed higher than expected rates, indicating that intramolecular participation of the hydroxyl group, which is known to accelerate peptide hydrolysis, is also likely to take place in these dipeptides. Finally, in some cases Lewis basic side-chains like carboxylates (Asp, Glu), carboxamide (Asn) and imidazole (His) were observed by ${ }^{1} \mathrm{H}$ and ${ }^{13} \mathrm{C}$ NMR to aid interaction with the catalyst, although direct coordination between these groups and the catalyst could not be evidenced. These interactions apparently played only a secondary role in these reactions, thus having a quite distinct role from prior artificial metalloproteases based on $\mathrm{Cu}(\mathrm{II})$ and $\mathrm{Pd}(\mathrm{II})$ complexes that required direct anchoring to the amino acid side chains. ${ }^{10,35}$ Moreover, the electrostatic interactions between the M-POM and the amino acid side chains also did not appear to play a relevant role in the hydrolysis of small peptides, although a rate increase was observed in some cases. 


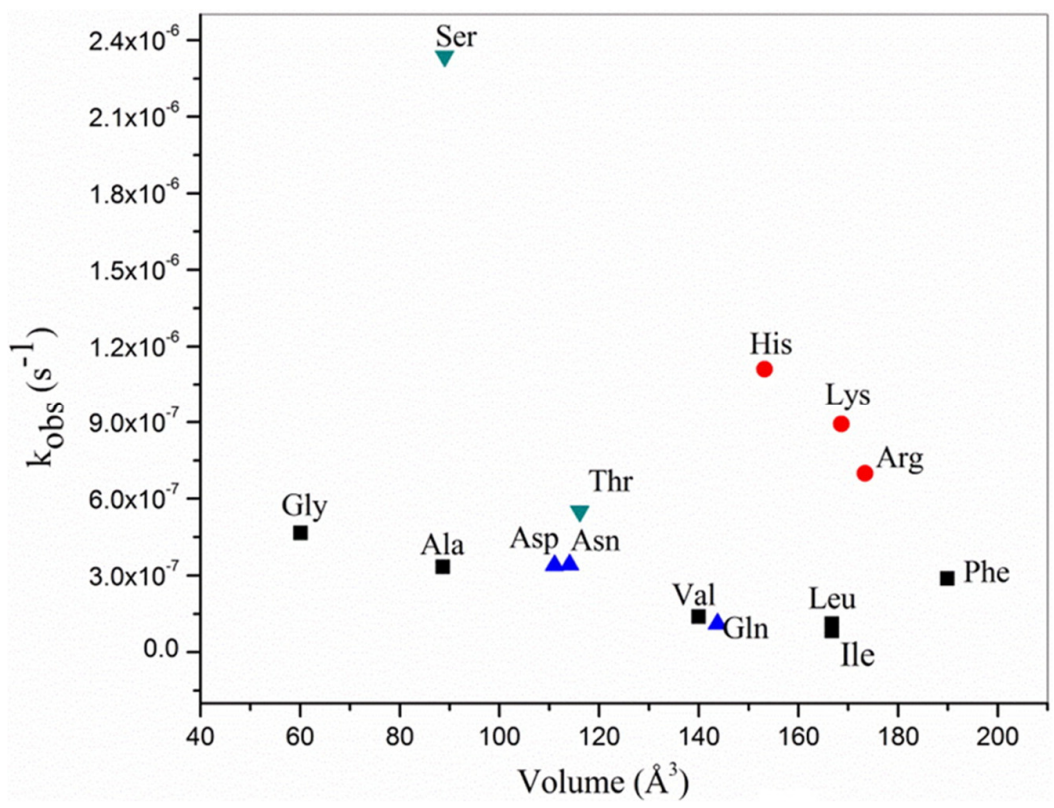

Figure 2: Reaction rates for the hydrolysis of Gly-X dipeptides showcases how the size and nature hydrophobic $(\boldsymbol{\square})$, positively-charged $(\bullet)$, hydrophilic $(\boldsymbol{\nabla})$, or carbonyl-containing $(\boldsymbol{\Delta})$ - of the peptide sidechain influences reaction rate and mechanism (representative chart for Zr-Wells-Dawson 4:2, reproduced with permission from ref. 31. Copyright (2015) American Chemical Society).

In view of the promising and rich reactivity with dipeptides, a gradual increase in the complexity of the systems was pursued by examining short oligopeptides ${ }^{28,36}$ and the oxidized insulin chain $\mathrm{B}$, an unstructured polypeptide consisting of 30 amino acids. ${ }^{37}$ In general, hydrolysis of tri- and tetrapeptides followed the same principles observed in dipeptides, and in the case of insulin chain B, the preferential hydrolysis at Gly8-Ser9, followed by Phe1-Val2, Gln4-His5, and Leu6-Cys $\left(\mathrm{SO}_{3} \mathrm{H}\right) 7$ matched very well the reactivity trends observed with dipeptides. ${ }^{37}$ These results clearly indicated that Lewis acid mediated cleavage of peptide bonds also occurred in larger molecules, and prompted us to probe the reactivity of MOCs with several protein substrates.

\section{SELECTIVE PROTEIN HYDROLYSIS BY MS-POMS}

Based on the deep understanding of the catalytic activity of metal-substituted POMs towards peptides, we relied on the catalytic potential of $\mathrm{Zr}(\mathrm{IV}), \mathrm{Hf}(\mathrm{IV})$ and $\mathrm{Ce}$ (IV) POMs (here referred as M-POMs) to explore the reactivity of MOCs with proteins. As a result, the selective hydrolysis of different proteins has been reported with a wide variety of intrinsic properties, such as isoelectric point (pI), size and surface charge by these M-POMs (Figure 3). ${ }^{2,3,38-41}$ Hereon, we showcase the tunability and selectivity of MOC catalysts to highlight their potential as promising artificial metalloproteases. 

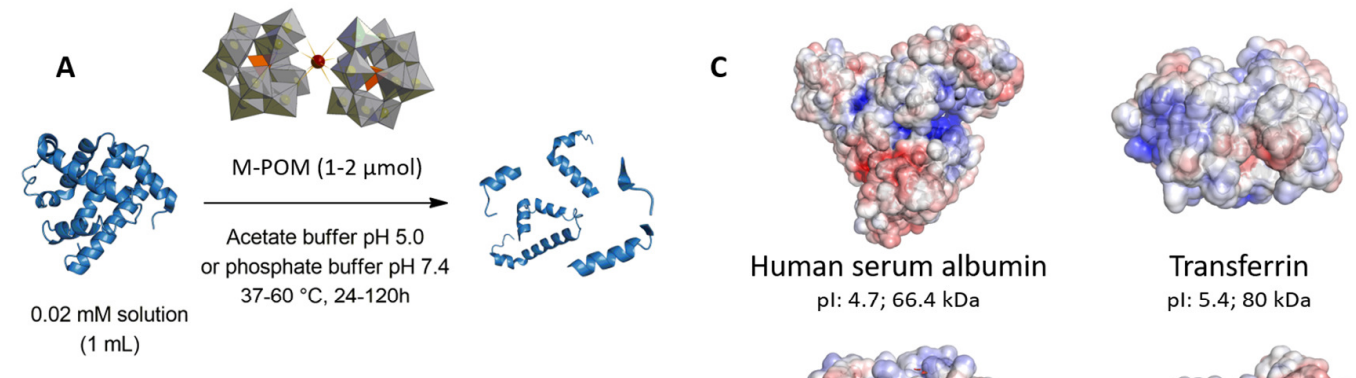

Human serum albumin Transferrin pl: $4.7 ; 66.4 \mathrm{kDa}$ pl: $5.4 ; 80 \mathrm{kDa}$

B
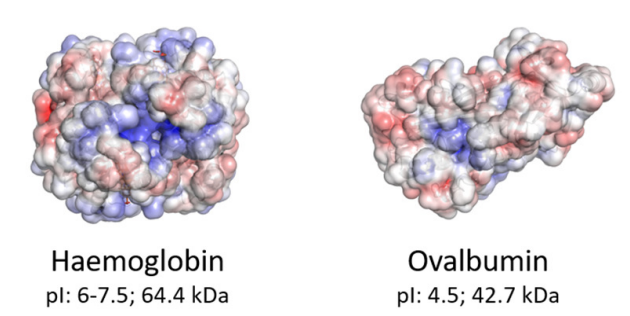

Ovalbumin pl: $6-7.5 ; 64.4 \mathrm{kDa}$ pl: $4.5 ; 42.7 \mathrm{kDa}$

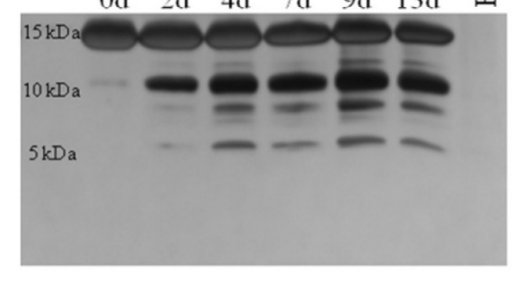

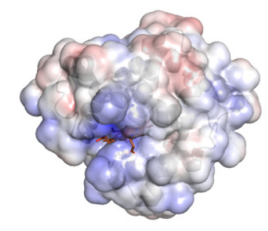

Myoglobin pl: 6.97; $16.7 \mathrm{kDa}$

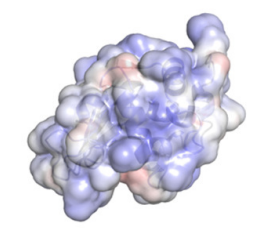

Lysozyme pl: $10.7 ; 14.3 \mathrm{kDa}$

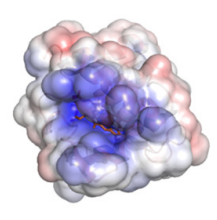

Cytochrome C pl: $9.8 ; 11.8 \mathrm{kDa}$

Figure 3: a) Metal-substituted POMs selectively hydrolyze proteins under mild reaction conditions. b) Sodium dodecyl-polyacrylamide gel electrophoresis (SDS-PAGE) analysis of protein fragments obtained after reaction illustrated with the hydrolysis of haemoglobin by 2:2 Zr-Keggin (reproduced with permission from ref. 2 . Copyright (2019) Wiley-VCH Verlag GmbH\&Co. KGaA.) c) Overview of selected proteins hydrolyzed by $\mathrm{Hf}^{\mathrm{IV}}-, \mathrm{Zr}^{\mathrm{IV}}-$ or $\mathrm{Ce}^{\mathrm{IV}}-\mathrm{POMs}$. At physiological $\mathrm{pH}$ blue areas are positively charged, red areas are negatively charged.

The hydrolysis of proteins with $\mathrm{Zr}(\mathrm{IV})-$, $\mathrm{Hf}(\mathrm{IV})$ - or Ce(IV)-substituted POMs under physiological $\mathrm{pH}$

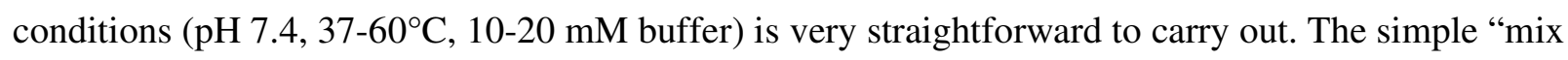
and incubate" nature of the reported reactions allowed for facile analysis by sodium dodecylpolyacrylamide gel electrophoresis (SDS-PAGE), revealing the formation of discrete, hydrolytically cleaved protein fragments in typically $24-48$ h. ${ }^{2,3,29,38,40-42}$ Usually, after 24 hours of reaction no new discrete protein fragments were observed but the ones already formed increased in intensity, evidencing that protein hydrolysis by M-POMs is selective in nature. Additionally, the smoothness of M-POM protein cleavage generates protein fragments in the range of 3-15 $\mathrm{kDa}$, which are suitable for middle-down proteomics. This emerging area of proteomics is highly promising as it reduces the inherent loss of information by analyzing larger protein fragments than the ones generated by established natural proteases such as trypsin.$^{43}$ 
The site selectivity of the hydrolysis was elucidated by Edman degradation, a standard N-terminal derivatization that allows the stepwise identification of N-terminal amino acids, which allowed identification of the specific peptide bonds that were cleaved (Table 1). Notably, among the many peptide bonds available in a single protein, M-POM complexes target specifically those that are solvent exposed and located in positive patches of the protein surface. Moreover, peptide bonds with polar charged side-chain residues were favored over the Lewis basic His and Cys residues that were targeted by other metallic complexes. ${ }^{10}$ More interestingly, identical cleavage patterns were observed for myoglobin in the presence of different Zr-POMs, regardless of the POM scaffold having a Lindqvist, Keggin or Wells-Dawson structure. ${ }^{40}$

Table 1. Selectivity of protein hydrolysis observed in presence MS-POMs

\begin{tabular}{|c|c|c|c|c|}
\hline Protein & $\begin{array}{c}\text { Number of } \\
\text { residues }\end{array}$ & $\begin{array}{c}\text { M-POM } \\
\left(\mathrm{M}=\mathrm{Zr}^{\mathrm{IV}}, \mathbf{H} \mathbf{f}^{\mathrm{IV}}, \mathrm{Ce}^{\mathrm{IV}}\right)\end{array}$ & $\begin{array}{r}\text { Number of } \\
\text { cleavages }\end{array}$ & Cleavage sites \\
\hline $\begin{array}{c}\text { Human serum } \\
\text { albumin }^{38}\end{array}$ & 585 & 1:2 Zr-Wells-Dawson & 4 & $\begin{array}{l}\text { Arg114-Leu115, } \\
\text { Ala257-Asp258, } \\
\text { Lys313-Asp314, } \\
\text { Cys392-Glu393 }\end{array}$ \\
\hline $\begin{array}{l}\text { Horse heart } \\
\text { myoglobin }^{40}\end{array}$ & 153 & 2:2 Zr-Keggin & 6 & $\begin{array}{l}\text { Asp4-Gly5, } \\
\text { Asp20-Ile21, } \\
\text { Asp44-Lys45, } \\
\text { Asp60-Leu61, } \\
\text { Asp126-Ala127, } \\
\text { Asp141-Ile142 }\end{array}$ \\
\hline Haemoglobin ${ }^{2}$ & $\begin{array}{c}572(2 \alpha 2 \beta) \\
\alpha \text {-subunit: } \\
141 \\
\beta \text {-subunit: } \\
145\end{array}$ & 2:2 Zr-Keggin & 11 & $\begin{array}{c}\alpha \text {-subunit: } \\
\text { Asp6-Lys7, } \\
\text { Asp74-Asp75, } \\
\text { Asp75-Leu76, } \\
\text { Asp85-Leu86, } \\
\text { Asp94-Pro95, } \\
\text { Asp116-Phe117 } \\
\beta \text {-subunit: } \\
\text { Asp46-Leu47, } \\
\text { Asp51-Ala52, }\end{array}$ \\
\hline
\end{tabular}




\begin{tabular}{|c|c|c|c|c|}
\hline & & & & $\begin{array}{l}\text { Asp68-Ser69, } \\
\text { Asp78-Asp79, } \\
\text { Asp98-Pro99 }\end{array}$ \\
\hline \multirow[b]{2}{*}{ Cytochrome $\mathbf{c}^{44}$} & \multirow[b]{2}{*}{104} & 1:2 Ce-Keggin & 2 & $\begin{array}{l}\text { Trp60-Lys61, } \\
\text { Gly78-Thr79 }\end{array}$ \\
\hline & & $\begin{array}{l}\text { 1:2 Zr-Keggin } \\
\text { 2:2 Zr-Keggin }\end{array}$ & 3 & $\begin{array}{c}\text { Asp3-Val, } \\
\text { Asp51-Ala52, } \\
\text { Gly78-Thr79 }\end{array}$ \\
\hline Ovalbumin $^{41}$ & 385 & 1:2 Hf-Wells-Dawson & 8 & $\begin{array}{l}\text { Phe13-Asp14, } \\
\text { Arg85-Asp86, } \\
\text { Asn95-Asp96, } \\
\text { Ala139-Asp140, } \\
\text { Ser148-Trp149, } \\
\text { Ala361-Asp362, } \\
\text { Asp362-His363, } \\
\text { Pro364-Phe365 }\end{array}$ \\
\hline \multirow[t]{2}{*}{$\begin{array}{c}\text { Hen Egg White } \\
\text { Lysozyme }^{3,29}\end{array}$} & \multirow[t]{2}{*}{129} & 1:2Hf- Wells-Dawson & 6 & $\begin{array}{l}\text { Asp18-Asn19, } \\
\text { Asp48-Gly49, } \\
\text { Thr51- Asp52, } \\
\text { Asp52-Tyr53, } \\
\text { Asp66-Gly67, } \\
\text { Asp101-Gly102 }\end{array}$ \\
\hline & & 1:2 Ce-Keggin & 2 & $\begin{array}{l}\text { Trp28-Val29, } \\
\text { Asn44-Arg45 }\end{array}$ \\
\hline
\end{tabular}

Remarkably, proteins greatly varying in size, $\mathrm{pI}$ and three-dimensional structure, such as human serum albumin (HSA), ${ }^{39}$ haemoglobin, ${ }^{2}$ Hen Egg White Lysozyme (HEWL), ${ }^{3}$ and ovalbumin ${ }^{41}$ (Figure $3 \mathrm{c}$ ), were predominantly hydrolyzed at Asp-X or X-Asp bonds, especially in the presence of $\mathrm{Hf}^{\mathrm{IV}}$ and $\mathrm{Zr}^{\mathrm{IV}}$ substituted POMs. This keen preference towards Asp sites is uncommon in natural proteases, even though Asp containing peptide bonds are among the most labile bonds in a peptide chain. ${ }^{45}$ Such favorable cleavage was rationalized by means of DFT calculations on the hydrolysis of a model peptide bearing an internal aspartate residue by a $\mathrm{Zr}^{\mathrm{IV}}$-Lindqvist complex. For the Asp-X linkages, the $\mathrm{Zr}$ POM was found to facilitate an intramolecular nucleophilic attack by the side-chain carboxylate group 
of aspartate residue to a backbone amide bond, leading to formation of a five-membered cyclic hemiaminal intermediate, which collapses to yield the final cleaved product and regenerated catalyst (Figure 4a). In comparison with its homologue glutamate, the aspartate intramolecular attack is favored mostly by slightly lower activation energies, and the different stability of the corresponding succinic and glutaric cyclic anhydrides formed (Figure 4b). On the other hand, the same intramolecular attack mechanism is not favored for the cleavage of X-Asp bonds and they probably undergo a conventional Lewis acid mechanism (Scheme 2). Here, the Asp carboxylate group might work more efficiently than other side-chain functional groups as an 'intramolecular base' that deprotonates the water molecule attacking the peptide bond, thus accelerating X-Asp cleavage in comparison to other peptide bonds, ${ }^{2}$ due to the kinetic preference for formation of five- over six-membered rings 
a)

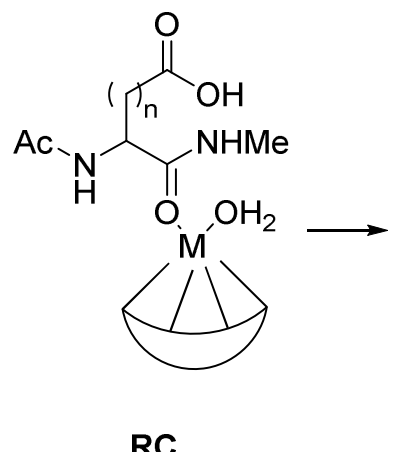

RC

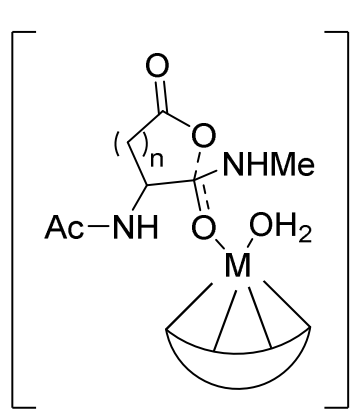

$\mathrm{TS}_{1}$

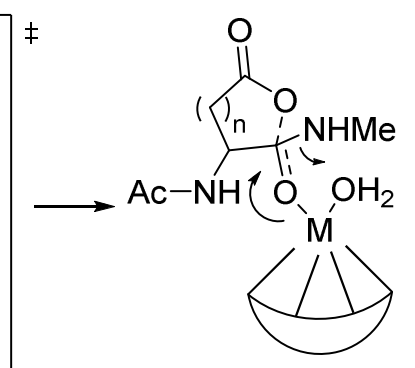

INT $_{1}$

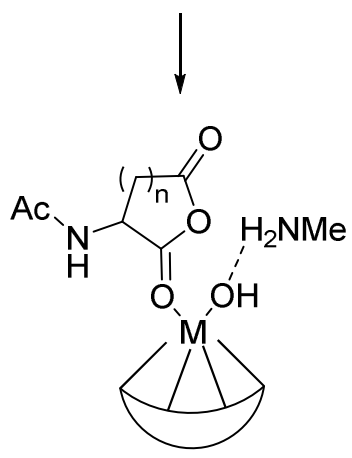

PC

b)

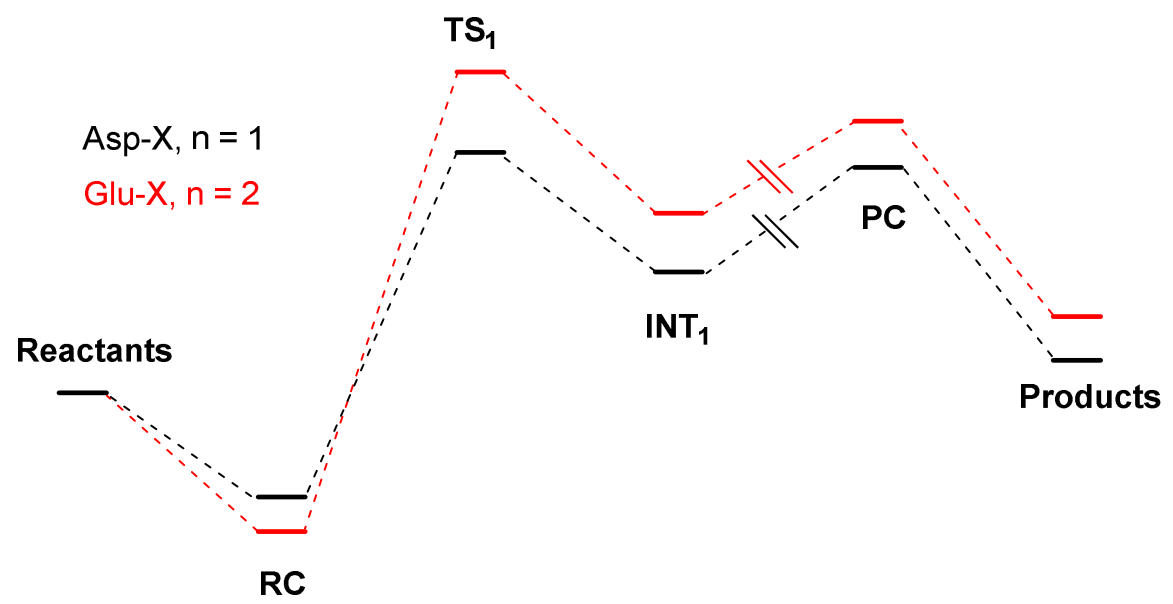

Figure 4: Simplified schematic representation of the a) key intermediates and b) energy profiles along the reaction path for the hydrolysis of Asp-X and Glu-X.

Finally, even though a similar cleavage pattern was obtained for the diverse group of proteins in Table 1 , some interesting differences in the outcome of the protein hydrolysis reactions were also observed depending on the metal embedded in the M-POM catalyst employed. For example, in the hydrolysis of cytochrome c with isostructural $\mathrm{Ce}^{\mathrm{IV}}$ - and $\mathrm{Zr}^{\mathrm{IV}}$-Keggin POMs, ${ }^{44}$ two peptide bonds were hydrolyzed 
by the former (Trp60-Lys61 and Gly78-Thr79), while three cleavage sites were obtained for the latter (Asp3-Val4, Asp51-Ala52 and Gly78-Thr79). Similarly, Ce ${ }^{\mathrm{IV}}$-Keggin hydrolyzed HEWL at only two bonds (Trp28-Val29 and Asn44-Arg45), while $\mathrm{Hf}^{\mathrm{IV}}$-Wells-Dawson cleaved six peptide bonds with exclusive Asp-selectivity (Asp18-Asn19, Asp48-Gly49, Thr51- Asp52, Asp52-Tyr53, Asp66-Gly67, Asp101-Gly102). The reasons behind these differences in selectivity are still not fully understood. However, partial reduction of $\mathrm{Ce}^{\mathrm{IV}}-$ Keggin to $\mathrm{Ce}^{\mathrm{III}}$-Keggin was observed during the reaction with both proteins, which likely affects the coordination chemistry and the reactivity of this M-POM catalyst. ${ }^{46}$ Detailed kinetic studies with a series of amino acids and peptides revealed that side chains of Cys, Trp, Tyr, Phe and His amino acids can reduce Ce ${ }^{\mathrm{IV}}-\mathrm{POMs} .{ }^{46}$ This study further confirmed that the protein's surface redox activity could alter the M-POMs reactivity if the embedded Lewis acid is a redox active element like Ce(IV).

\section{THE ROLE OF POM-PROTEIN INTERACTIONS IN THE HYDROLYSIS OF PROTEINS}

To gain a better understanding of the reactivity and selectivity profile observed for metal-substituted POMs towards proteins, we carried out several experiments to elucidate how M-POMs and proteins interact. In early work with coordination complexes, selectivity was primarily achieved through conventional coordination chemistry. ${ }^{10,35}$ However, even though the embedded Lewis acid metal is what renders the M-POM hydrolytically active, the interaction between the POM framework and the proteins is an important first step to bring the Lewis acid in close proximity to the reactive amide bond. ${ }^{47}$ Such importance was directly observed in the hydrolysis of HSA by $\mathrm{Zr}^{\mathrm{IV}}$-Wells-Dawson 1:2, in the absence and presence of a surfactant. ${ }^{38,39}$ The presence of surfactant affects the protein structure and consequently POM-protein interactions, allowing for the tuning of the cleavage sites. ${ }^{38,39}$ Such interactions have been frequently studied by X-ray crystallography,${ }^{20}$ but have been less explored in solution. Therefore, we have studied in detail how these interactions affect speciation of the POM catalyst on one hand, and selectivity of protein hydrolysis on the other.

The metal-substituted POM activation of peptide bonds, which presumably takes place through interaction with the carbonyl oxygen atom of the peptide backbone, requires free coordination sites at the embedded Lewis acidic metal (Scheme 2). However, several of the protein hydrolysis reactions were conducted using coordinatively saturated 1:2 complexes, which would need to undergo an unfavorable dissociation in physiological $\mathrm{pH}$ to become catalytically active. ${ }^{28,30}$ This puzzling contradiction prompted us to investigate the effect of proteins in the speciation of M-POMs by both experimental and theoretical methods. More specifically, HEWL was co-crystallized with Zr-Keggin 1:2, Zr-Keggin 2:2 and Hf-Wells-Dawson 1:2 complexes. Interestingly, all resulting structures were obtained containing only the monomeric M-POM units. ${ }^{3,41}$ Such predominance of monomeric species 
was further examined with theoretical calculations, which revealed an unexpected relationship between the dielectric constant of the medium and M-POM speciation. At the protein surface, which has a lower dielectric constant $(\varepsilon \approx 20-30$ ), dissociation is favored due to both stabilization of the MPOM 1:1 species by the protein surface, and decreasing of the shielding towards the electrostatic repulsion between anionic POM ligands provided by solvent media with higher dielectric constants, such as water $(\varepsilon \approx 80) .{ }^{3}$ Together, these results indicate that the protein actually favors the formation of catalytic active M-POM 1:1 species, which is consistent with the hydrolysis taking place regardless of the precursor used.

Further analysis of protein-POM crystal structures also revealed that the M-POM 1:1 complexes were located in the vicinity of observed cleavage sites. The Hf-Wells-Dawson was found to be interacting with HEWL at three distinct sites either in direct or close proximity to Asp-cleaved sites observed upon digestion of HEWL with $\mathrm{Hf}^{\mathrm{IV}}$-Wells-Dawson 1:2 (Figure 5), ${ }^{3}$ and a similar scenario was observed for $\mathrm{Zr}^{\mathrm{IV}}$-Keggin/HEWL co-crystals. ${ }^{48,49}$ The similar crystal structures of the HEWL/monomeric $\mathrm{Zr}^{\mathrm{IV}}$-Keggin complex obtained with either 1:2 $\mathrm{Zr}^{\mathrm{IV}}$-Keggin or 2:2 $\mathrm{Zr}^{\mathrm{IV}}$-Keggin, also attested to the prominent role of the POM framework in the interaction of metal-substituted POMs with proteins. Furthermore, when the crystal structure was prepared using the $\mathrm{Zr}^{\mathrm{IV}}$-Keggin $2: 2$ precursor, in one of the interaction sites the embedded $\mathrm{Zr}^{\mathrm{IV}}$ metal center was oriented towards the carbonyl oxygen atom of asparagine 65 of HEWL, thereby mimicking the interactions putatively responsible for the activation of the peptide bond. ${ }^{49}$ Both the prominence of POM scaffolds in the interactions and the ability of the embedded Lewis acidic metal to complex amide bonds are consistent with the reaction mechanism rationalized using dipeptide substrates (Scheme 2) and the protein hydrolysis observed in Table 1. 

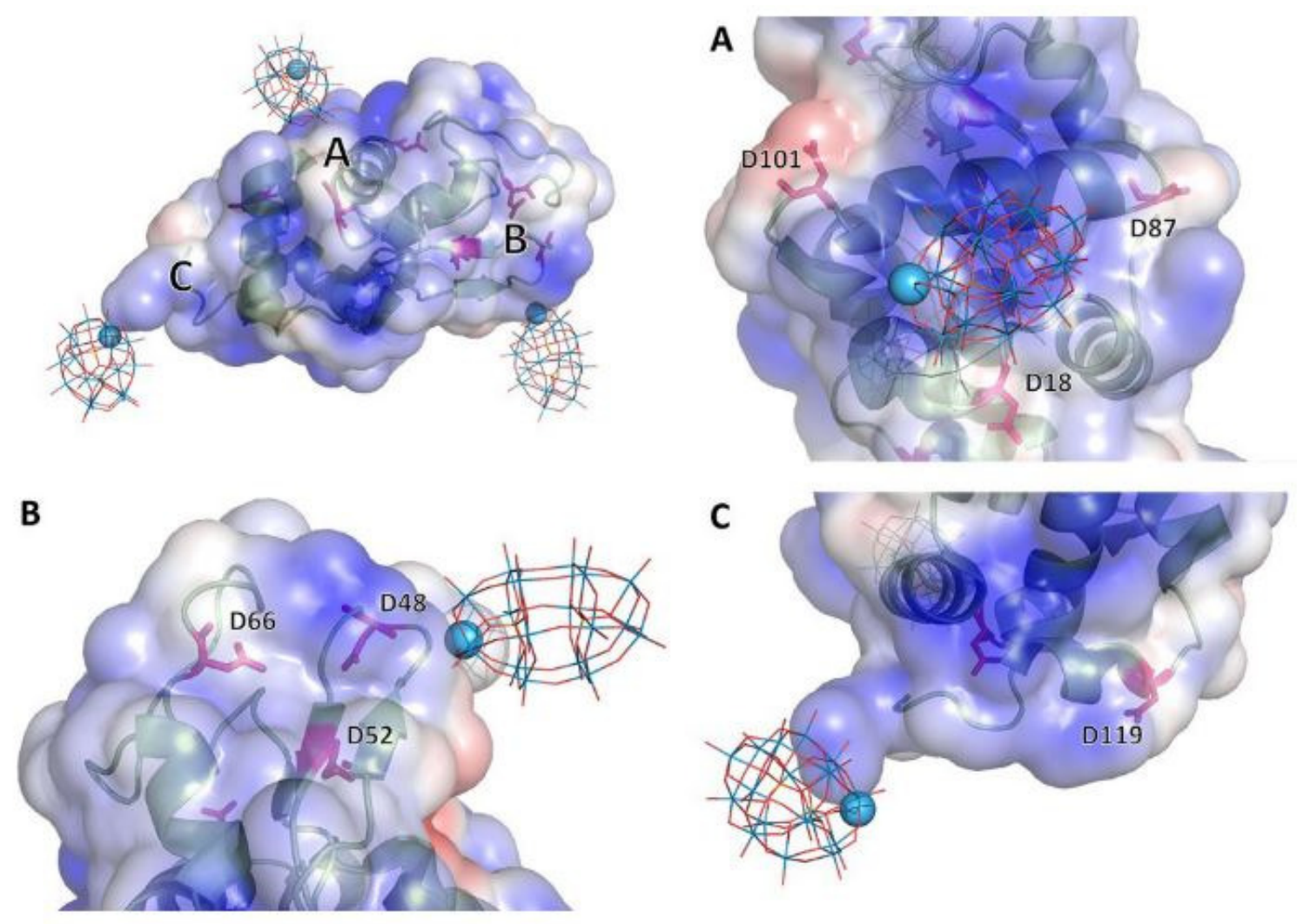

Figure 5: Overview of the three different binding sites of Hf-Wells-Dawson near D18-D87-D101 (a), D48D52-D66 (b) and D119 (c) on the positive patches of Hen Egg White Lysozyme (HEWL) surface. Hf(IV): blue sphere, POM as lines, protein: pale green cartoon with Asp-residues as magenta sticks (reproduced with permission from ref. 3. Copyright (2018) Wiley-VCH Verlag GmbH\&Co. KGaA).

Another interesting feature evident in the crystallographic structures was the preference of metalsubstituted POMs for the positively charged protein surfaces. The charged residues on protein surfaces permit an electrostatic interaction with negatively charged POM frameworks, and are likely driving forces in the observed M-POM assisted protein hydrolysis. ${ }^{29,39,42,44,50-55}$ The importance of electrostatic interactions between proteins and MS-POMs was clearly observed by tryptophan (Trp) fluorescence spectroscopy. The quenching of Trp fluorescence in proteins in the presence of exogenous ligands gives insight into the strength of the interaction, ${ }^{56}$ and was found to depend on both the nature of protein and M-POMs. ${ }^{39,42,50-53}$ In these experiments, the observed fluorescence quenching was attributed to the electrostatic interaction of M-POMs with the protein surface, and this was further strengthened by comparing the Trp fluorescence quenching in $\alpha$-lactalbumin $(\alpha$-LA) and HEWL. Even though HEWL and $\alpha$-LA are structurally highly homologous, the quenching constant was two orders of magnitude lower for $\alpha$-LA compared to HEWL, due to very different surface potentials with $\alpha$-LA 
being mainly negatively charged and HEWL being positively charged at physiological $\mathrm{pH}$. The quenching constants were consistent with the hydrolysis of HEWL and the absence of $\alpha$-LA hydrolysis observed in the presence of $\mathrm{Ce}^{\mathrm{IV}}$-Keggin, thereby supporting the hypothesis that attractive electrostatic interactions between the M-POMs framework and proteins are crucial for the observed reactivity. ${ }^{52}$ The mainly electrostatic nature of the interactions between MS-POMs and proteins was further confirmed in a broad X-ray crystallographic study of four different metal-substituted Wells-Dawson POMs $\left[\mathrm{M}^{\mathrm{n}}\left(\alpha_{2}-\mathrm{P}_{2} \mathrm{~W}_{17} \mathrm{O}_{61}\right)\right]^{\mathrm{n}-12}\left(\mathrm{M}^{\mathrm{n}+}=\mathrm{Zr}^{4+}, \mathrm{Co}^{2+}, \mathrm{Ni}^{2+}, \mathrm{Cu}^{2+}\right)$ bound in a non-covalent complex with HEWL. ${ }^{57}$ Each POM exhibited very similar interactions with HEWL at flexible loop-like parts with positively charged residues, such as arginine, lysine and asparagine. This behavior indicates that mainly electrostatic, and to a lesser extent water-mediated hydrogen bonding interactions between the POM framework and the protein surface are the driving force for the hydrolytic reaction to take place. These interactions observed in crystallo were further supported by molecular dynamics and molecular docking calculations, ${ }^{54,55}$ which confirmed that M-POM/protein binding is mainly driven by electrostatic interactions and direct or solvent-mediated hydrogen bonds. These interactions arise between the basic oxygens in the POM framework and the side chains of positively charged (arginine and lysine) and polar non-charged (tyrosine, serine and asparagine) amino acids. However, the strength of the interaction varied with the number of positively charged side-chains involved in the interactions, leading to energetically more favored binding sites when more charged side chains were present. ${ }^{54,55}$ Furthermore, the extent to which metal-substituted POMs influence the protein structure was investigated by Circular Dichroism (CD) spectroscopy. Secondary protein structures, such as alphahelices and beta-sheets are sensitive to ligand binding, providing a measure for the integrity of the overall structure of proteins upon ligand binding or interaction. ${ }^{58}$ Using CD spectroscopy, several protein/M-POM couples have been investigated. ${ }^{29,39,42,44,50,53}$ Generally, the introduction of an M-POM species was observed to affect the $\alpha$-helical and $\beta$-sheet secondary structure content of the protein, with the perturbation extent dependent on the size and charge of both M-POM and protein. In general, M-POMs had more pronounced effect on the secondary structure of smaller proteins; however, the native 3D fold of the proteins remained largely intact in most of the binding studies. Moreover, larger perturbations were observed upon addition of larger POMs such as Zr-Wells-Dawson 4:2 compared to the smaller Zr-Keggin or Zr-Lindqvist POMs. ${ }^{29,44,50}$ It is clear that a larger POM framework causes a greater structural perturbation of a protein; however, this did not necessarily correlate with a higher hydrolytic reactivity. Although somewhat intriguing, this is not surprising since the POM-protein interactions should be followed up by other key mechanistic steps, such as the formation of the catalytic active 1:1 species and its interaction with the amide carbonyl oxygen, in order to result in effective cleavage of the peptide bond. 


\section{HETEROGENEOUS GROUP IV MOC AS THE NEXT GENERATION OF ARTIFICIAL METALLOPROTEASES - EN ROUTE TO EFFICIENT NANOZYMES}

Even though most of our work has focused on metal-substituted POMs, our recent efforts have been dedicated towards developing the catalytic activity of other Lewis acidic $\mathrm{Zr}(\mathrm{IV})$ - and $\mathrm{Hf}(\mathrm{IV})$-oxo clusters for the peptide bond hydrolysis in model dipeptides and proteins. Besides expanding our studies related to the reactivity between MOCs and biomolecules, these clusters are conveniently available as heterogeneous materials, which could facilitate MOC and protein digest separation and streamline the analysis of generated protein fragments. These new research interests resulted in pioneering contributions reporting the protease activity of $\mathrm{Zr}_{6}$-based metal-organic frameworks (MOFs) and discrete Hf-oxo clusters, thus indicating a promising future role for these materials in the development of artificial hydrolytic nanozymes. ${ }^{59}$

Recently, we have shown that a large, discrete $\mathrm{Hf}^{\mathrm{IV}}$-based metal-oxo cluster, $\left[\mathrm{Hf}_{18} \mathrm{O}_{10}(\mathrm{OH})_{26}\left(\mathrm{SO}_{4}\right)_{13}\left(\mathrm{H}_{2} \mathrm{O}\right)_{33}\right](\mathbf{H f} \mathbf{1 8})$, selectively hydrolyzes Horse Heart Myoglobin (HHM) at Asp$\mathrm{X}$ and X-Asp peptide bonds (Figure 6) ${ }^{60}$ The $\mathbf{H f} \mathbf{f s}_{\mathbf{1 8}}$ cluster is insoluble in water, but could hydrolyze HHM through a combined action of Lewis acid $\mathrm{Hf}^{\mathrm{IV}}$ centers and the Brønsted acidic surface of $\mathbf{H f} \mathbf{1 8}$, resulting in cleavage of two Asp sites located in negative patches of the protein that previously remained unreacted when MS-POMs were used as catalysts. ${ }^{40,60}$ Notably, protein and cluster were found to strongly interact, resulting in complete adsorption of HHM onto the solid cluster surface after a few minutes. Although this interaction still hinders full recovery of protein fragments, initial mechanistic studies pointed to the stability of the cluster under the reaction conditions, indicating potential recyclability of the catalyst. Moreover, previous reports have already shown Lewis acid mediated hydrolysis of proteins by $\mathrm{Hf}^{\mathrm{IV}}$-substituted POMs, but $\mathbf{H f} \mathbf{1 8}$ provided a first proof that a combination of Lewis and Brønsted functionalities could be applied to future catalyst design. Additionally, this was the first report that used a heterogeneous discrete metal-oxo cluster as an allinorganic protease, which, considering the vast variety of metal-oxo cluster-based materials, promises a broad scope for future studies and applications. 
a)

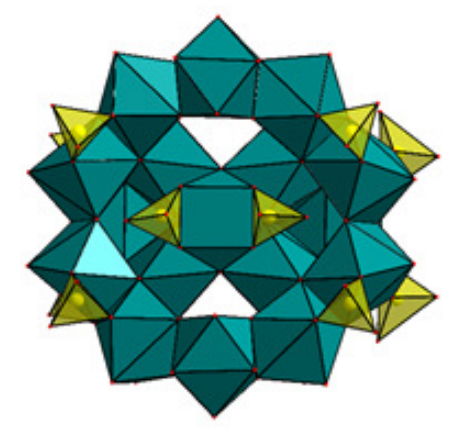

b)

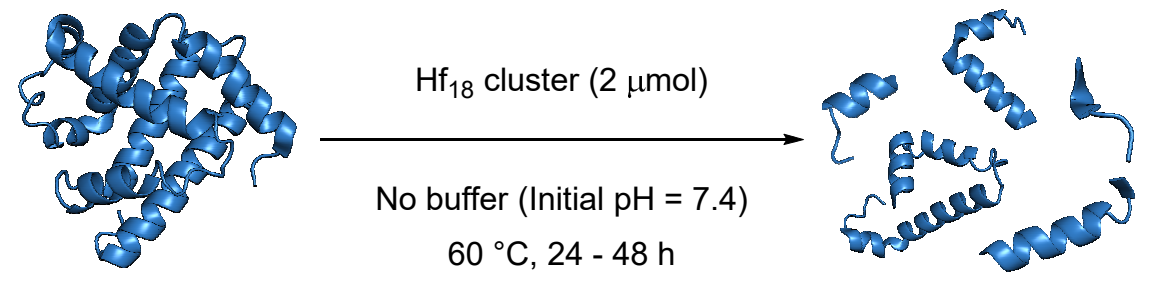

$0.02 \mathrm{mM}$ solution

(1 $\mathrm{mL})$

Figure 6: a) $\mathrm{Hf}^{\mathrm{IV}}$-based metal-oxo cluster, $\left[\mathrm{Hf}_{18} \mathrm{O}_{10}(\mathrm{OH})_{26}\left(\mathrm{SO}_{4}\right)_{13} \cdot\left(\mathrm{H}_{2} \mathrm{O}\right)_{33}\right]\left(\mathbf{H f}_{18}\right)$. Hafnium polyhedral: teal, sulfate polyhedral: yellow. ${ }^{60}$ b) $\mathbf{H f}_{\mathbf{1 8}}$ hydrolyzes Horse Heart Myoglobin (HHM) under simple mix and stir conditions. (reproduced with permission from ref. 60, Copyright (2020) Wiley-VCH Verlag GmbH \&Co. $\mathrm{KGaA}$ ).

In addition to discrete clusters, extended structures like MOFs have also exhibited promising hydrolytic activity towards peptides and proteins. MOFs are a diverse group of porous network materials based on metal ions or metal-oxo clusters linked by rigid organic linkers, whose structure tunability grants them excellent catalytic potential, among other applications. ${ }^{61}$ Based on the superior peptidase activity observed for $\mathrm{Zr}-\mathrm{POMs}$, MOFs based on $\mathrm{Zr}_{6} \mathrm{O}_{8}$ clusters such as MOF-808, ${ }^{4}$, UiO$66^{62}$ and NU-1000 63 were explored for their peptidase activity (Figure 7). Notably, all three MOFs hydrolyzed the Gly-Gly model substrate faster than Zr-POMs, suggesting that Zr-oxo clusters lower the energy barrier of peptide bond cleavage more efficiently than soluble metal-substituted POMs. Furthermore, the MOF network structure directly impacts the reaction rates, which decrease in the order MOF-808 > > NU-1000 > UiO-66. This behavior is probably due to the diverse accessibility of the presumed $\mathrm{Zr}_{6} \mathrm{O}_{8}$ catalytic sites, the different number of free coordination sites on $\mathrm{Zr}(\mathrm{IV})$ resulting from distinct MOF connectivity, as well as differences in pore size, shape, and even particle size. More interestingly, in this preliminary work we already observed that tuning the properties of the pore directly tunes MOF hydrolytic activity. For example, by changing the 3D octa- and tetrahedral shape 
of MOF-808's pores to the '2D channels' of NU-1000 significantly increased the entropy of activation, showing that MOF architecture directly impacts the reaction energetics. ${ }^{63}$ Similarly, introducing functional groups and/or modulating the number of defects in the UiO-66 structure resulted in different hydrolytic efficiencies for a range of dipeptides, indicating that residue selectivity might result from distinct pore decorations. ${ }^{62}$

A

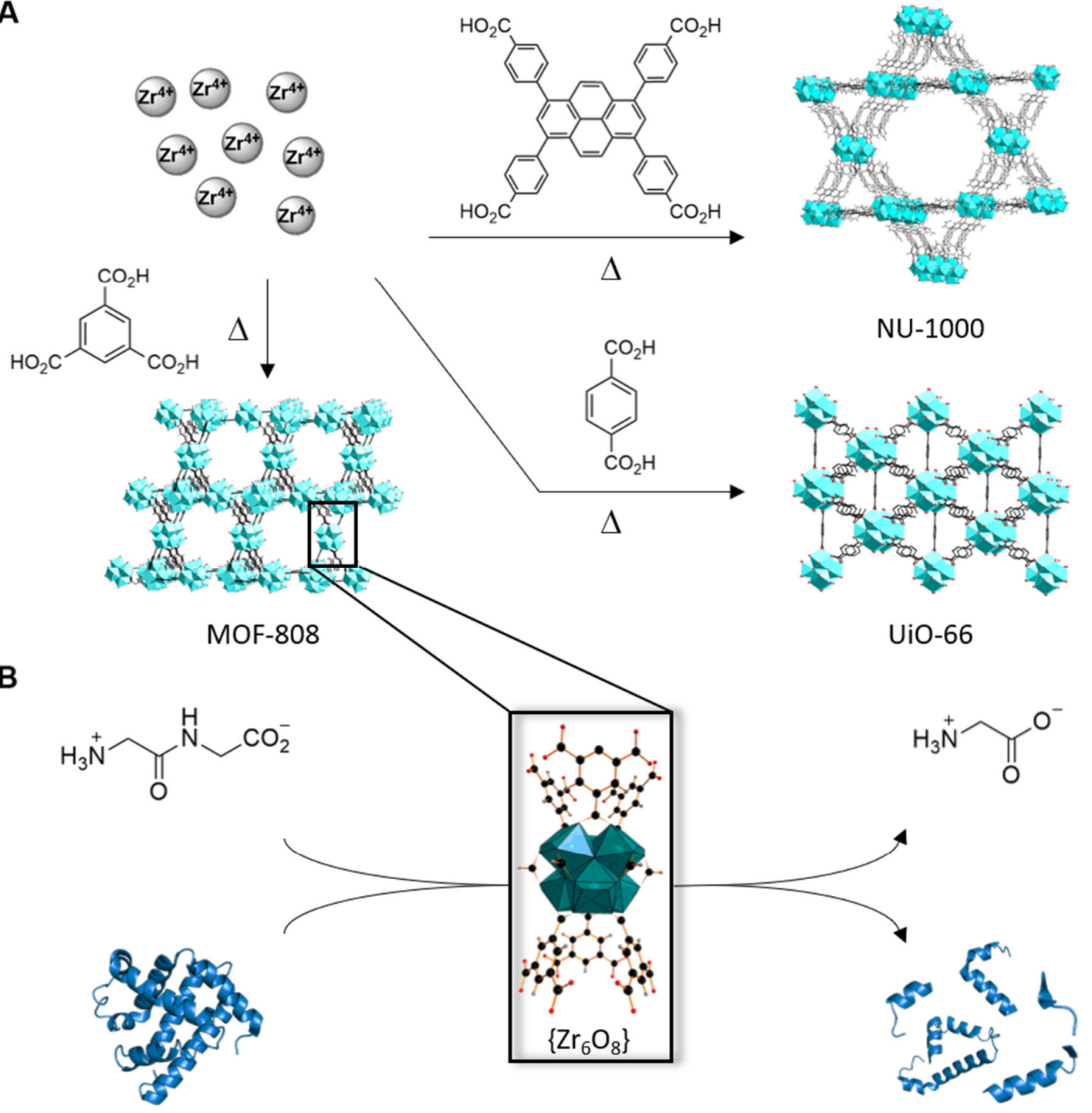

Figure 7: a) Highly porous MOF networks, NU-1000, ${ }^{63}$ UiO- $66^{62}$ and MOF- $808^{4}$ available from simple molecular components. b) $\left\{\mathrm{Zr}_{6} \mathrm{O}_{8}\right\}$ clusters embedded in the extended MOF-808 network are catalytically active towards the hydrolysis of peptides and proteins with high selectivity. Color code: $\left\{\mathrm{Zr}_{6} \mathrm{O}_{8}\right\}$ clusters: turquoise or teal, C: black, O: red.

Finally, these three Zr-MOFs also exhibited exquisite protease activity towards the HEWL model protein substrate, providing similar cleavage pattern by SDS-PAGE analysis, thus suggesting the 
reactivity is largely governed by the $\mathrm{Zr}_{6}$-oxo cluster embedded in the structure. Further comparison with the protein hydrolysis using metal-substituted POMs allowed us to speculate that these MOFs are Asp-selective proteases as well, thus underlining the potential of these materials as selective hydrolytic nanozymes. This prospect is further enhanced by the remarkable stability of the Zr-MOFs under the reactions conditions, in contrast to the prompt decomposition of a $\mathrm{Cu}^{\mathrm{II}}-\mathrm{MOF}$ (HKUST-1) observed during hydrolysis of bovine serum albumin. ${ }^{64}$

\section{CONCLUSIONS AND OUTLOOK}

Our quest to develop the hydrolytic activity of metal-oxo clusters towards peptide bonds is ongoing, but it has already resulted in many important insights for catalysis and bioinorganic chemistry. Here, we have summarized the key factors that influence the protein and peptide hydrolysis catalyzed by metal-substituted POMs, and provided insight into this scarcely explored area of polyoxometalates' reactivity. Altogether, the complementary experimental and theoretical studies have painted a rich and insightful picture of the different molecular and supramolecular features of the interactions between M-POM complexes and proteins that drive hydrolysis. Interestingly, they suggest that the POM framework quite remarkably engages in an "enzyme-like" non-covalent interaction with specific regions of the protein, placing the embedded metal nearby the position where it selectively cleaves the protein backbone. In addition to this controlled regioselectivity, the metal-substituted POM also imparts the relaxation of the secondary structure of the protein upon binding, which might be essential to make potential cleavage sites more accessible to the embedded Lewis acid. These features are strikingly similar to the control that natural proteases have over their substrates, which highlights the unique potential of M-POMs to behave as true artificial metalloproteases. Further, we have shown that the concepts uncovered with homogeneous metal-substituted POMs can be leveraged to explore other heterogeneous MOCs such as discrete metal-oxo clusters and MOFs, that also exhibit a very promising potential to be developed as hydrolytic nanozymes. Naturally, the complete design and control of all features that are characteristic for enzymes is still far away, but these first steps certainly show the promising opportunities of inorganic clusters to contribute to this gigantic multidisciplinary endeavor.

\section{AUTHOR INFORMATION}

\section{Corresponding Author}

Tatjana N. Parac-Vogt - Laboratory of Bioinorganic Chemistry, Department of Chemistry, KU Leuven, Celestijnenlaan 200F, 3001 Leuven, Belgium. ORCID: orcid.org/0000-0002-6188-3957 Email: tatjana.vogt@kuleuven.be Web page: https://lbc.chem.kuleuven.be/ 


\section{Authors}

Jens Moons - Laboratory of Bioinorganic Chemistry, Department of Chemistry, KU Leuven, Celestijnenlaan 200F, 3001 Leuven, Belgium.

Francisco de Azambuja - Laboratory of Bioinorganic Chemistry, Department of Chemistry, KU Leuven, Celestijnenlaan 200F, 3001 Leuven, Belgium. ORCID: orcid.org/0000-0002-5537-5411

\section{Notes}

The authors declare no competing financial interest.

\section{Biographies}

Tatjana N. Parac-Vogt is a full professor of chemistry at KU Leuven. She studied chemistry at the University of Belgrade, former Yugoslavia, and obtained her PhD from Iowa State University in USA. Following her $\mathrm{PhD}$, she enjoyed postdoctoral stays at the group of Professor Ken Raymond (University of California, Berkeley, USA), and Germany as an Alexander von Humboldt Fellow. In 2000, she moved to KU Leuven, where she currently leads the Laboratory of Bioinorganic Chemistry. She is actively interested in promoting gender and cultural diversity in the working environment, and coaching and mentoring younger female scientists.

Jens Moons is a biochemist educated at KU Leuven. As a PhD student in the group of Prof. ParacVogt, he developed homogeneous and heterogeneous metal-oxo clusters for the selective hydrolysis of proteins.

Francisco de Azambuja is an organic chemist interested in catalysis and catalytic materials. Educated in Brazil (PhD 2015, State University of Campinas), Germany and USA, in 2018 he landed in Belgium to develop novel reactions and metal-oxide based catalysts as alternatives to sensitive conventional transition metal catalysts.

\section{ACKNOWLEDGMENTS}

T.N.P.-V. thanks KU Leuven and Research Foundation Flanders for financial support. T.N.P.-V. and J.M. are grateful to the European Commission (Horizon 2020 project FoodEnTwin, GA No. 810752). F.d.A. thanks FWO for fellowship (195931/1281921N). The authors thank MSc. Charlotte Simms and Dr. Laurens Vandebroek for assisting with some images.

\section{REFERENCES}

(1) Mihaylov, T. T.; Ly, H. G. T.; Pierloot, K.; Parac-Vogt, T. N. Molecular Insight from DFT Computations and Kinetic Measurements into the Steric Factors Influencing Peptide Bond 
Hydrolysis Catalyzed by a Dimeric $\mathrm{Zr}(\mathrm{IV})$-Substituted Keggin Type Polyoxometalate. Inorg. Chem. 2016, 55, 9316-9328. https://doi.org/10.1021/acs.inorgchem.6b01461.

(2) Ly, H. G. T.; Mihaylov, T. T.; Proost, P.; Pierloot, K.; Harvey, J. N.; Parac-vogt, T. N. Chemical Mimics of Aspartate-Directed Proteases: Predictive and Strictly Specific Hydrolysis of a Globular Protein at Asp-X Sequence Promoted by Polyoxometalate Complexes Rationalized by a Combined Experimental and Theoretical Approach. Chem. Eur. J. 2019, 25, 14370-14381. https://doi.org/10.1002/chem.201902675.

(3) Vandebroek, L.; De Zitter, E.; Ly, H. G. T.; Conić, D.; Mihaylov, T.; Sap, A.; Proost, P.; Pierloot, K.; Van Meervelt, L.; Parac-Vogt, T. N. Protein-Assisted Formation and Stabilization of Catalytically Active Polyoxometalate Species. Chem. Eur. J. 2018, 24, 10099-10108. https://doi.org/10.1002/chem.201802052.

(4) Ly, H. G. T.; Fu, G.; Kondinski, A.; Bueken, B.; De Vos, D.; Parac-Vogt, T. N. Superactivity of MOF808 toward Peptide Bond Hydrolysis. J. Am. Chem. Soc. 2018, 140, 6325-6335. https://doi.org/10.1021/jacs.8b01902.

(5) Yaoyang Zhang; Fonslow, B. R.; Shan, B.; Baek, M.-C.; III, J. R. Y. Protein Analysis by Shotgun/Bottom-up Proteomics. Chem Rev 2013, 113, 2343-2394. https://doi.org/10.1038/jid.2014.371.

(6) Klein, T.; Eckhard, U.; Dufour, A.; Solis, N.; Overall, C. M. Proteolytic Cleavage - Mechanisms, Function, and "Omic" Approaches for a Near-Ubiquitous Posttranslational Modification. Chem. Rev. 2018, 118, 1137-1168. https://doi.org/10.1021/acs.chemrev.7b00120.

(7) Lee, T. Y.; Suh, J. Target-Selective Peptide-Cleaving Catalysts as a New Paradigm in Drug Design. Chem. Soc. Rev. 2009, 38, 1949-1957. https://doi.org/10.1039/b710345j.

(8) Luh, L. M.; Scheib, U.; Jünemann, K.; Wortmann, L.; Brands, M.; Cromm, P. M. Prey for the Proteasome: Targeted Protein Degradation - A Medicinal Chemist's Perspective. Angew. Chem. Int. Ed. 2020, 59, 15448-15466. https://doi.org/10.1002/anie.202004310.

(9) Grant, K.; Kassai, M. Major Advances in the Hydrolysis of Peptides and Proteins by Metal lons and Complexes. Curr. Org. Chem. 2006, 10, 1035-1049. https://doi.org/10.2174/138527206777435535.

(10) Wezynfeld, N. E.; Frączyk, T.; Bal, W. Metal Assisted Peptide Bond Hydrolysis: Chemistry, Biotechnology and Toxicological Implications. Coord. Chem. Rev. 2016, 327-328, 166-187. https://doi.org/10.1016/j.ccr.2016.02.009.

(11) Pope, M. T. Introduction to Polyoxometalate Chemistry. In Polyoxometalate Molecular Science; Borrás-Almenar, J. J., Coronado, E., Müller, A., Pope, M., Eds.; Springer Netherlands: Dordrecht, 2003; pp 3-31.

(12) Gross, S. Oxocluster-Reinforced Organic-Inorganic Hybrid Materials: Effect of Transition Metal Oxoclusters on Structural and Functional Properties. J. Mater. Chem. 2011, 21, 15853-15861. https://doi.org/10.1039/c1jm10579e.

(13) Miras, H. N.; Yan, J.; Long, D. L.; Cronin, L. Engineering Polyoxometalates with Emergent Properties. Chem. Soc. Rev. 2012, 41, 7403-7430. https://doi.org/10.1039/c2cs35190k.

(14) Wang, S. S.; Yang, G. Y. Recent Advances in Polyoxometalate-Catalyzed Reactions. Chem. Rev. 2015, 115, 4893-4962. https://doi.org/10.1021/cr500390v.

(15) Misra, A.; Kozma, K.; Streb, C.; Nyman, M. Beyond Charge Balance: Counter-Cations in Polyoxometalate Chemistry. Angew. Chem. Int. Ed. 2020, 59, 596-612. https://doi.org/10.1002/anie.201905600.

(16) Yamase, T. Anti-Tumor, -Viral, and -Bacterial Activities of Polyoxometalates for Realizing an Inorganic Drug. J. Mater. Chem. 2005, 15, 4773-4782. https://doi.org/10.1039/b504585a.

(17) Bijelic, A.; Aureliano, M.; Rompel, A. The Antibacterial Activity of Polyoxometalates: Structures, 
Antibiotic Effects and Future Perspectives. Chem. Commun. 2018, 54, 1153-1169. https://doi.org/10.1039/c7cc07549a.

(18) Bijelic, A.; Aureliano, M.; Rompel, A. Polyoxometalates as Potential Next-Generation Metallodrugs in the Combat Against Cancer. Angew. Chem. Int. Ed. 2019, 58, 2980-2999. https://doi.org/10.1002/anie.201803868.

(19) Čolović, M. B.; Lacković, M.; Lalatović, J.; Mougharbel, A. S.; Kortz, U.; Krstić, D. Z. Polyoxometalates in Biomedicine: Update and Overview. Curr. Med. Chem. 2020, 27, 362-379.

(20) Bijelic, A.; Rompel, A. The Use of Polyoxometalates in Protein Crystallography - An Attempt to Widen a Well-Known Bottleneck. Coord. Chem. Rev. 2015, 299, 22-38. https://doi.org/10.1016/j.ccr.2015.03.018.

(21) Absillis, G.; Cartuyvels, E.; Van Deun, R.; Parac-Vogt, T. N. Hydrolytic Cleavage of an RNA-Model Phosphodiester Catalyzed by a Highly Negatively Charged Polyoxomolybdate $\left[\mathrm{Mo}_{7} \mathrm{O}_{24}\right]^{6-}$ Cluster. J. Am. Chem. Soc. 2008, 130, 17400-17408. https://doi.org/10.1021/ja804823g.

Steens, N.; Ramadan, A. M.; Parac-Vogt, T. N. When Structural and Electronic Analogy Leads to Reactivity: The Unprecedented Phosphodiesterase Activity of Vanadates. Chem Commun 2009, No. 8, 965-967. https://doi.org/10.1039/b816785k.

(23) De Clercq, K.; Persoons, E.; Napso, T.; Luyten, C.; Parac-Vogt, T. N.; Sferruzzi-Perri, A. N.; Kerckhofs, G.; Vriens, J. High-Resolution Contrast-Enhanced MicroCT Reveals the True ThreeDimensional Morphology of the Murine Placenta. Proc. Natl. Acad. Sci. U. S. A. 2019, 116, 13927-13936. https://doi.org/10.1073/pnas.1902688116.

(24) Ho, P. H.; Stroobants, K.; Parac-Vogt, T. N. Hydrolysis of Serine-Containing Peptides at Neutral $\mathrm{PH}$ Promoted by $\left[\mathrm{MoO}_{4}\right]^{2-}$ Oxyanion. Inorg. Chem. 2011, 50, 12025-12033. https://doi.org/10.1021/ic2015034.

(25) Ho, P. H.; Mihaylov, T.; Pierloot, K.; Parac-Vogt, T. N. Hydrolytic Activity of Vanadate toward Serine-Containing Peptides Studied by Kinetic Experiments and DFT Theory. Inorg. Chem. 2012, 51, 8848-8859. https://doi.org/10.1021/ic300761g.

(26) Stroobants, K.; Ho, P. H.; Moelants, E.; Proost, P.; Parac-Vogt, T. N. Selective Hydrolysis of Hen Egg White Lysozyme at Asp-X Peptide Bonds Promoted by Oxomolybdate. J. Inorg. Biochem. 2014, 136, 73-80. https://doi.org/10.1016/j.jinorgbio.2014.03.006.

(27) Gumerova, N. I.; Rompel, A. Polyoxometalates in Solution: Speciation under Spotlight. Chem. Soc. Rev. 2020, 49, 7568-7601. https://doi.org/10.1039/d0cs00392a.

(28) Absillis, G.; Parac-Vogt, T. N. Peptide Bond Hydrolysis Catalyzed by the Wells-Dawson $\operatorname{Zr}\left(\alpha_{2^{-}}\right.$ $\left.\mathrm{P}_{2} \mathrm{~W}_{17} \mathrm{O}_{61}\right)_{2} \quad$ Polyoxometalate. Inorg. Chem. 2012, 51, 9902-9910. https://doi.org/10.1021/ic301364n.

(29) Stroobants, K.; Moelants, E.; Ly, H. G. T.; Proost, P.; Bartik, K.; Parac-Vogt, T. N. Polyoxometalates as a Novel Class of Artificial Proteases: Selective Hydrolysis of Lysozyme under Physiological PH and Temperature Promoted by a Cerium(IV) Keggin-Type Polyoxometalate. Chem. Eur. J. 2013, 19, 2848-2858. https://doi.org/10.1002/chem.201203020.

(30) Ly, H. G. T.; Absillis, G.; Parac-Vogt, T. N. Amide Bond Hydrolysis in Peptides and Cyclic Peptides Catalyzed by a Dimeric Zr(IV)-Substituted Keggin Type Polyoxometalate. Dalton Trans. 2013, 42, 10929-10938. https://doi.org/10.1039/c3dt50705j.

(31) Ly, H. G. T.; Mihaylov, T.; Absillis, G.; Pierloot, K.; Parac-Vogt, T. N. Reactivity of Dimeric Tetrazirconium(IV) Wells-Dawson Polyoxometalate toward Dipeptide Hydrolysis Studied by a Combined Experimental and Density Functional Theory Approach. Inorg. Chem. 2015, 54, 11477-11492. https://doi.org/10.1021/acs.inorgchem.5b02122.

Radzicka, A.; Wolfenden, R. Rates of Uncatalyzed Peptide Bond Hydrolysis in Neutral Solution 
and the Transition State Affinities of Proteases. J. Am. Chem. Soc. 1996, 118, 6105-6109. https://doi.org/10.1021/ja954077c.

(33) de Azambuja, F.; Lenie, J.; Parac-Vogt, T. N. Homogeneous Metal Catalysts with Inorganic Ligands: Probing Ligand Effects in Lewis Acid Catalyzed Direct Amide Bond Formation. ACS Catal. 2021, 11, 271-277. https://doi.org/10.1021/acscatal.0c04189.

(34) de Azambuja, F.; Parac-Vogt, T. N. Water-Tolerant and Atom Economical Amide Bond Formation by Metal-Substituted Polyoxometalate Catalysts. ACS Catal. 2019, 9, 10245-10252. https://doi.org/10.1021/acscatal.9b03415.

Mahesh, S.; Tang, K. C.; Raj, M. Amide Bond Activation of Biological Molecules. Molecules 2018, 23, 1-43. https://doi.org/10.3390/molecules23102615.

Ly, H. G. T.; Absillis, G.; Parac-Vogt, T. N. Comparative Study of the Reactivity of Zirconium(IV)Substituted Polyoxometalates towards the Hydrolysis of Oligopeptides. Eur. J. Inorg. Chem. 2015, 2015, 2206-2215. https://doi.org/10.1002/ejic.201500161.

Sap, A.; Absillis, G.; Parac-Vogt, T. N. Selective Hydrolysis of Oxidized Insulin Chain B by a Zr(Iv)Substituted Wells-Dawson Polyoxometalate. Dalton Trans. 2015, 44, 1539-1548. https://doi.org/10.1039/c4dt01477d.

Stroobants, K.; Absillis, G.; Moelants, E.; Proost, P.; Parac-Vogt, T. N. Regioselective Hydrolysis of Human Serum Albumin by Zr(IV)-Substituted Polyoxotungstates at the Interface of Positively Charged Protein Surface Patches and Negatively Charged Amino Acid Residues. Chem. Eur. J. 2014, 20, 3894-3897. https://doi.org/10.1002/chem.201303622.

(39) Sap, A.; Vandebroek, L.; Goovaerts, V.; Martens, E.; Proost, P.; Parac-Vogt, T. N. Highly Selective and Tunable Protein Hydrolysis by a Polyoxometalate Complex in Surfactant Solutions: A Step toward the Development of Artificial Metalloproteases for Membrane Proteins. ACS Omega 2017, 2, 2026-2033. https://doi.org/10.1021/acsomega.7b00168.

(40) Ly, H. G. T.; Absillis, G.; Janssens, R.; Proost, P.; Parac-Vogt, T. N. Highly Amino Acid Selective Hydrolysis of Myoglobin at Aspartate Residues as Promoted by Zirconium(IV)-Substituted Polyoxometalates. Angew. Chem. Int. Ed. 2015, 54, 7391-7394. https://doi.org/10.1002/anie.201502006.

(41) Anyushin, A. V; Sap, A.; Quanten, T.; Proost, P.; Parac-Vogt, T. N. Selective Hydrolysis of Ovalbumin Promoted by $\mathrm{Hf}(\mathrm{IV})$-Substituted Wells-Dawson-Type Polyoxometalate. Front. Chem. 2018, 6, 1-9. https://doi.org/10.3389/fchem.2018.00614.

(42) Moons, J.; Van Rompuy, L. S.; Rodriguez, A.; Abdelhameed, S. A. M.; Simons, W.; Parac-Vogt, T. N. Hydrolysis of Transferrin Promoted by a Cerium(IV)-Keggin Polyoxometalate. Polyhedron 2019, 170, 570-575. https://doi.org/10.1016/j.poly.2019.06.010.

(43) Pandeswari, P. B.; Sabareesh, V. Middle-down Approach: A Choice to Sequence and Characterize Proteins/Proteomes by Mass Spectrometry. RSC Adv. 2019, 9, 313-344. https://doi.org/10.1039/C8RA07200K.

(44) Sap, A.; Van Tichelen, L.; Mortier, A.; Proost, P.; Parac-Vogt, T. N. Tuning the Selectivity and Reactivity of Metal-Substituted Polyoxometalates as Artificial Proteases by Varying the Nature of the Embedded Lewis Acid Metal Ion. Eur. J. Inorg. Chem. 2016, 2016, 5098-5105. https://doi.org/10.1002/ejic.201601098.

(45) Schultz, J.; Allison, H.; Grice, M. Specificity of the Cleavage of Proteins by Dilute Acid. I. Release of Aspartic Acid from Insulin, Ribonuclease, and Glucagon. Biochemistry 1962, 1, 694-698.

(46) Abdelhameed, S. A. M.; Vandebroek, L.; De Azambuja, F.; Parac-Vogt, T. N. Redox Activity of $\mathrm{Ce}(\mathrm{IV})$-Substituted Polyoxometalates toward Amino Acids and Peptides. Inorg. Chem. 2020, 59, 10569-10577. https://doi.org/10.1021/acs.inorgchem.0c00993.

(47) Van Rompuy, L. S.; Parac-Vogt, T. N. Interactions between Polyoxometalates and Biological 
Systems: From Drug Design to Artificial Enzymes. Curr. Opin. Biotechnol. 2019, 58, 92-99. https://doi.org/10.1016/j.copbio.2018.11.013.

(48) Sap, A.; De Zitter, E.; Van Meervelt, L.; N. Parac-Vogt, T. Structural Characterization of the Complex between Hen Egg-White Lysozyme and Zr $r^{\mathrm{IV}}$-Substituted Keggin Polyoxometalate as Artificial Protease. Chem. Eur. J. 2015, 21, 11692-11695. https://doi.org/https://doi.org/10.1002/chem.201501998.

(49) Vandebroek, L.; Van Meervelt, L.; Parac-Vogt, T. N. Direct Observation of the Zr ${ }^{\prime V}$ Interaction with the Carboxamide Bond in a Noncovalent Complex between Hen Egg White Lysozyme and a Zr-Substituted Keggin Polyoxometalate. Acta Crystallogr. Sect. C Struct. Chem. 2018, 74, 1348-1354. https://doi.org/10.1107/S2053229618010690.

(50) Ly, H. G. T.; Parac-Vogt, T. N. Spectroscopic Study of the Interaction between Horse Heart Myoglobin and Zirconium(IV)-Substituted Polyoxometalates as Artificial Proteases. ChemPhysChem 2017, 18, 2451-2458. https://doi.org/10.1002/cphc.201700680.

(51) Goovaerts, V.; Stroobants, K.; Absillis, G.; N. Parac-Vogt, T. Understanding the Regioselective Hydrolysis of Human Serum Albumin by $\mathrm{Zr}(\mathrm{IV})$-Substituted Polyoxotungstates Using Tryptophan Fluorescence Spectroscopy. Inorganics 2015, 3, 230-245. https://doi.org/10.3390/inorganics3020230.

(52) Goovaerts, V.; Stroobants, K.; Absillis, G.; Parac-Vogt, T. N. Eu(III) Luminescence and Tryptophan Fluorescence Spectroscopy as a Tool for Understanding Interactions between Hen Egg White Lysozyme and Metal-Substituted Keggin Type Polyoxometalates. J. Inorg. Biochem. 2015, 150, 72-80. https://doi.org/10.1016/j.jinorgbio.2015.03.015.

(53) Quanten, T.; Mayaer, T. De; Shestakova, P.; Parac-vogt, T. N. Selectivity and Reactivity of Zr'V and $\mathrm{Ce}^{\mathrm{lV}}$ Substituted Keggin Type Polyoxometalates Toward Cytochrome $\mathrm{c}$ in Surfactant Solutions. Front. Chem. 2018, 6, 1-13. https://doi.org/10.3389/fchem.2018.00372.

(54) Paul, T. J.; Parac-vogt, T. N.; Quiñonero, D.; Prabhakar, R. Investigating Polyoxometalate Protein Interactions at Chemically Distinct Binding Sites. J. Phys. Chem. 2018, 122, 7219-7232. https://doi.org/10.1021/acs.jpcb.8b02931.

(55) Solé-Daura, A.; Goovaerts, V.; Stroobants, K.; Absillis, G.; Jiménez-Lozano, P.; Poblet, J. M.; Hirst, J. D.; Parac-Vogt, T. N.; Carbó, J. J. Probing Polyoxometalate-Protein Interactions Using Molecular Dynamics Simulations. Chem. Eur. J. 2016, 22, 15280-15289. https://doi.org/10.1002/chem.201602263.

(56) Mocz, G.; Ross, J. A. Fluorescence Techniques in Analysis of Protein-Ligand Interactions. In Protein-Ligand Interactions. Methods in Molecular Biology (Methods and Protocols); Williams, M.; Daviter, T., Ed.; Humana Press: Totowa, NJ, 2013; Vol. 1008, pp 169-210. https://doi.org/10.1007/978-1-62703-398-5.

(57) Vandebroek, L.; Mampaey, Y.; Antonyuk, S.; Van Meervelt, L.; Parac-Vogt, T. N. Noncovalent Complexes Formed between Metal-Substituted Polyoxometalates and Hen Egg White Lysozyme. Eur. J. Inorg. Chem. 2019, 2019, 506-511. https://doi.org/10.1002/ejic.201801113.

(58) Greenfield, N. J. Using Circular Dichroism Spectra to Estimate Protein Secondary Structure. Nat. Protoc. 2007, 1, 2876-2890. https://doi.org/10.1038/nprot.2006.202.

(59) Huang, Y.; Ren, J.; Qu, X. Nanozymes: Classification, Catalytic Mechanisms, Activity Regulation, and Applications. Chem. Rev. 2019, 119, 4357-4412. https://doi.org/10.1021/acs.chemrev.8b00672.

(60) Moons, J.; de Azambuja, F.; Mihailovic, J.; Kozma, K.; Smiljanic, K.; Amiri, M.; CirkovicVelickovic, T.; Nyman, M.; Parac-Vogt, T. N. Discrete $\mathrm{Hf}_{18}$ Metal-oxo Cluster as a Heterogeneous Nanozyme for Site-specific Proteolysis. Angew. Chem. Int. Ed. 2020, 59, 90949101. https://doi.org/10.1002/anie.202001036. 
(61) Furukawa, H.; Cordova, K. E.; O’Keeffe, M.; Yaghi, O. M. The Chemistry and Applications of $\begin{array}{llll}\text { Metal-Organic } \quad \text { Frameworks. } & \text { 2013, 341, } 1230444 .\end{array}$ https://doi.org/10.1126/science.1230444.

(62) Ly, H. G. T.; Fu, G.; de Azambuja, F.; De Vos, D. E.; Parac-Vogt, T. N. Nanozymatic Activity of UiO-66 Metal-Organic Frameworks: Tuning the Nanopore Environment Enhances Hydrolytic Activity toward Peptide Bonds. ACS Appl. Nano Mater. 2020. https://doi.org/10.1021/acsanm.0c01688.

(63) Loosen, A.; de Azambuja, F.; Smolders, S.; Moons, J.; Simms, C.; De Vos, D.; Parac-Vogt, T. N. Interplay between Structural Parameters and Reactivity of Zr6-Based MOFs as Artificial Proteases. Chem. Sci. 2020, 11, 6662-6669. https://doi.org/10.1039/d0sc02136a.

(64) Li, B.; Chen, D.; Wang, J.; Yan, Z.; Jiang, L.; Duan, D.; He, J.; Luo, Z.; Zhang, J.; Yuan, F. MOFzyme: Intrinsic Protease-like Activity of Cu-MOF. Sci. Rep. 2014, 4, 39-43. https://doi.org/10.1038/srep06759. 